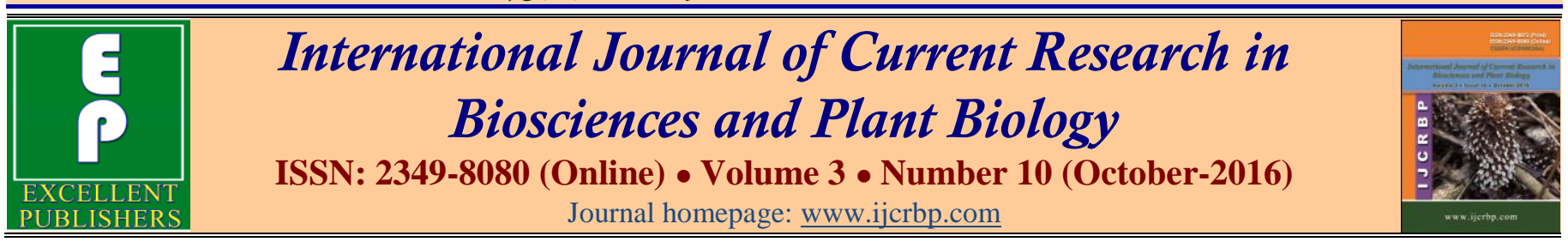

Original Research Article

doi: $\underline{\text { http://dx.doi.org/10.20546/ijcrbp.2016.310.012 }}$

\title{
The Ministry of Public Health of Marginal Social Studies Perspective in Indonesia
}

\author{
M. Kes Darwis* \\ Lecturer, STIKES Nani Hasanuddin Makassar, South Sulawesi, Indonesia \\ *Corresponding author.
}

\begin{abstract}
A bstract
This type of research qualitative with approach through phenomenology, the source of the data in this study include: the source of primary data and secondary data sources. Poverty indeed currently constitutes an obstacle in the community or in the broader scope of Ron. Poverty is becoming a social problem because when poverty starts multiply numbers, then the existing crime will increase. Many people are currently translating poverty as the base causes social and economic problems. Poverty is now becoming a social problem when the stratification of society in respect of already created levels or dividing lines. So the existence of any discrepancy or boundary demarcation in the interaction or communication between people who are at levels below and above it.
\end{abstract}

\section{Article Info}

Accepted: 16 September 2016

Available Online: 06 October 2016

\section{Keywords}

Community

Marginal

Poverty

Social studies

\section{Introduction}

Poverty is a State of wherein happened incapacity to meet basic needs such as food, clothing, shelter, education and health. Poverty can be caused by a scarcity of basic needs, locally abundant tools or difficulty of access to education and jobs. Poverty is understood in different ways. The main understanding includes: a shortage of material, which usually include the daily food needs, clothing, housing, and health services. Poverty in this sense is understood as a situation of scarcity of goods and basic services. An overview of social needs, including social, dependency, and the inability to participate in the community. This includes education and information. Social Keterkucilan is usually distinguished from poverty, as this includes the issues of politics and morals, and not restricted to the economic sphere. An overview about the lack of an adequate income and wealth. The poverty problem has indeed been long in existence since ancient times. In the recent past generally been poor society, not because of lack of food, but the poor in the form of lack of ease or material. About the size of modern life in the present, they do not enjoy the facilities of education, healthcare, and other amenity available in the modern era. Poverty as a social disease of the economy, not only experienced by countries that are developing, but also developed countries, like the United Kingdom and the United States.

Poverty continues to be phenomenal problems throughout the history of Indonesia as a nation state, the history of a country that looked wrong and take care of poverty. In a country that is mismanaged, there is no greater issue, other than the question of poverty. Poverty has made millions of children could not be pursuing a quality education, the difficulties of financing health care, lack of savings and the lack of investment, lack of 
access to public services, lack of jobs, lack of social security and protection for the family, the rise of urbanization to the city, and a more severe poverty, causing millions of people to meet the needs of food, clothing and boards are limited. Poverty, causing the villagers willing to sacrifice anything for the sake of survival, safety, life, risking the physical power to produce profits for the local middleman and receive wages that are not commensurate with the cost of energy expended.

Indonesia is an area with a very diverse population, both in terms of race, tribe, ethnicity and culture. So with the very different circumstances of the vulnerable gave rise to various problems. Currently, humans living in the modern era with the feature of progress in all fields. The construction of tall buildings with various luxurious facilities for the Government. While on one side of the many communities that do not have jobs also live in a slum. Seen here a social gap between government officials with ordinary society.

In Indonesia, the poverty community in modern life is defined do not enjoy the facilities of education, health service and other conveniences available in the modern era. Poverty in all countries is always in together with a problem rate of population growth, which later gave birth to unemployment, low education who became the main capital of the competitive world of work today. Health care is a fundamental right of the community to be met in health development. It should be viewed as an investment for the improvement of the quality of human resources and supporting economic development, as well as having an important role in poverty reduction efforts. Important issues in health services, among others, health status disparity; the double burden of disease; quality, equity and affordability of health services; shield cover communities in the field of medicine and food; as well as the behavior of living clean and healthy. Some of the other important issues that need to be dealt with immediately is increased access of the population of the poor against health service, handling the issue of malnutrition, outbreaks of infectious disease prevention, health services in the disaster area, and the fulfillment of the amount and distribution of health workers.

\section{Problems}

A. How are access and barriers to medical services for the poor in Indonesia

B. How the concept of poverty as a part of social issues

\section{Nature of social problem}

Defenitional social problems of many experts who expressed his opinion about the social problem, among others: Soekanto (1995), asserts that social problems will occur, when the reality faced by the citizens of the community different from his expectations. It further said that social issues concerning the problems that occur in the process of social interaction.

Roucek in Abdulsyaini (1994), defines social issues as a problem involving a large number of human beings in ways that hinder the accomplishment of social and biological wills set out to follow the line of the emphasize community.

The cause of the onset of a social Problem the incidence of social problems is generally caused by certain factors, such as a less stable economy, biological factors, psychological factors and cultural factors. Real existence in public life is usually an assortment like suicide, disorganization, mental illness and others. According to the opinion of the Horald Phelps at Abdulsyani (1994:193), there are 4 sources of social problems, namely:

a. That derives from economic factors, among others, including poverty, unemployment and so on.

b. Originating from biological factors, among others, includes physical diseases and disabilities.

c. Caused by psychological factors, such as the pain-pain nerves, soul, weak memory.

d. Caused by cultural factors, such as the problems of old age, does not have a place of residence, crime, juvenile delinquency, disputes of religion, tribe, and race.

Furthermore, Daldjoeni stated that social problems can be associated with natural problems or personal problems. According to him there are some causes of the incidence of social problems, namely:

1. Natural Factors (ecological-geographical), it concerns the symptoms of depletion of natural resources. The cause can be an act of excessive exploitation by humans with an increasingly advanced technology.

2. Biological factors (in terms of population), it concerns the increase of the population rapidly perceived nationally, regionally or locally. According to Ellwood (quoted by Bouman: 1976), that element of the biological imperatives is:

a. The urge to eat, according to a fact of experience that eat more easily done with the cooperation of the 
individual by the Act on.

b. Encouragement of self-preservation, especially at State primritif of growth of living human flesh, then the urge for self focus should be a whip to cooperate.

c. The urge to walk type, especially for the maintenance of lineage and kinship.

3. Motivation Factor is the development of technology (communications and transportation) and its implications in the economic life of the religious law, education, as well as the usage of spare time.

4. Social Factors, within the meaning of the various economic and political wisdom are controlled in the community.

5. The approach in the settlement of social issues a. Sectoral approach to human life includes various sectors that must be faced. Each of the sectors have the characters and issues that need to be taken care of by myself anyway. E.g. different economic issues with political matters and issues of culture (Team Builder ISD, 1982:135). By looking at a problem need to see first the sectors of what was to become the main factor. This sectoral approach is very necessary, because we will not be able to see the issue as a whole, without knowing what parts do exist in it.

\section{An integrated approach}

The issue that concerns people's lives are in fact interrelated to each other. Existing social problems often concern the various disciplines. So it is a combination that is difficult to separate. How to resolve a problem that can not only be seen in terms of a single course or sectoral nature alone, but must be integrated. How to approach which used highly determined by the scope of the issue at hand (Team Builder ISD, 1982:136) Understanding social problems and examples as well as cause - you can learn about the definition of social issues clearly and complete below.

\section{The social structure of society}

The social structure is the order or arrangement of the social life in the community in which the reciprocal relationship between continued the status and role of the device with the limits of social elements that pointed at a behavioral the regularity so as to provide the form as a society (Soekanto, 1983). While (Shanin, 1971) argues that the social structure of the village is special circumstances for certain areas and within the specified time. However, according to Shanin, there is no concept of a social layer that can be used to explain social reality precisely certain farmers 'groups, so that attempts to uncover the class structure of society is a difficult problem.

It was discovered by difficulty (Beteille, 1977:119-125) when trying to formulate a formal definition of the class by the way comparing between different models of interpretation of the existing class structure with a social reality which is found in the agricultural societies in India. Beetle found no single formal definition of a class that is fully satisfactory as seen from the ability to explain the social symptoms not only logically and consistent but also at once a keenly sociological sense shows the category class generated by these definitions.

Further Beteille explained that the Division of class society in usually follows two kinds of formal approach, i.e. the dichotomy of approach and the approach of gradations. Relying on the existence of a dichotomy of approach relationships of dependency between two categories of class in relation to ownership, control, and land use, such as the relationship between owners of land by peasants. Approach the dichotomy has excellence in it shows the sense of sociological among relationships of the various categories of classes shown, but has a weakness in terms of explaining the relationship between the consistency of the various categories. As an example the relationship of dependency between the two categories of classes in relation to the possession and use of land, such as the relationship between the owner of the land by the peasants. The model of this Division is not able to explain how the nature of the relationship between the categories when faced with the symptoms of the number of relatively narrow land owners free from dependence on the extensive landowners and is not employed or hired laborer.

Talking about social structures in a society could not be released from the thoughts of Marx and Weber, regarding the social stratification dimensions. The classic Marx's thesis about the social stratification system is very closely related to the existence of a class of inequality caused by differences in the life of the economy, especially regarding the mode of production. It is therefore the view of Marx put more emphasis on economic aspects that determine the position class (Charon, 1980:109-114).

\section{Perspective of poverty in Indonesia}

The position of humans in the process of development, especially in rural development is resource highlights, considering the number of inhabitants of the village of 
potential. Rural areas generally detained by characteristic low-income inhabitants, low productivity, low levels of education, health and nutrition relative less supported by the low level of well-being. This was the State of the development goals. Because their life needs to be increased, especially to overcome the poverty of the villagers left behind. Poverty alleviation is the multidimensional activities. Not only related to the target of education, but also focusing the fulfillment of basic human needs (human basic need) that have to be dealt with. The fulfillment of basic human needs is not another opportunity gain health, nutrition, sufficient income, education, opportunity and prosperous family life.

Poverty is usually defined as a situation that does not allow a correct fulfillment of basic necessities. The special properties of the nation, society and even ethnicity accounted for in defining the nature, composition and number of basic necessities are concerned. But in order to utilize the concept of determining poverty line, scientists used biological norms that are normally expressed in the amount of food consumed. Although the main objection against its methodology (individual variations will be the need of the foodstuffs; assessment for input, but not for output; the collection problems, and others), but the definition of a poverty line based on income required to purchase a certain number of minimum basic necessities, a procedure that has been tested with pragmatic enough so the aligned with data collected on a macroeconomic level (Gsänger, 1988).

Further Gsänger convey that; the assessment of the dimensions of the poverty line in the region, namely the calculation of qualitative level and nature of poverty, was carried out based on the data collected from the national household research results. The definition of norms nutrition done on the recommendation of the Department of health and the FAO. The recommended amount is considered based on average prices is happening in village Java. Emil Salim (1976) in Supriyatna (1997) suggests five characteristics of the poor population. The fifth characteristic of the poor population is:

1. Do not have their own production factor

2. Does not have the possibility to acquire the asset production with own power

3. The level of education in General rendah4. Many of those who do not have the facilities

5. Among those aged relatively young and have no skills or education.
Poor population groups residing in rural and urban communities, generally landless laborers, farmer farms, hawkers, scavenger, tramp, beggar (sprawl), and unemployment (Supriyatna, 1997). This group will pose a continuing problem for the cultural and structural poverty, if not handled in concentration, especially for the next generation. In General, the population is classified as poor was the residual, i.e. groups of people who have not been touched by a range of government policies that open their hearts in particular, such as through the IDT. But in general, it's been through the BIMAS program, PKT, Program revenue increase of farmers and fishermen, village, PKK in the village, etc. This group was difficult to touch, because the quality of resources that low so less utilize the facilities, including contributing factors of production. They also have less ability, low education levels, training is very minimal, including harness the granting of assistance for basic human needs, and the protection of the law or legislation favoring them none the less.

\section{Poverty is a social reality}

Poverty becomes something, of course. Most people take that kind of attitude, or poverty is indeed a "naturalness" which was certainly there. The definition of this kind would restrict the insights our thinking on a State that is certain and, of course, occur in conditions of life. Opening a poverty problem that should be well thought out and complete because it was within the bounds of reasonableness. But the poor people we saw celebrating her son's wedding, invite neighbors and friends. But one day we will see the House of the poor man's last poundinon people who collect debts. Two "realities" that last we saw, started to doubt a word "reasonable". We will think; looking for: for causing or perhaps connected with other things.

To get answers to these questions are not simple, not like asking people on the street or from the data. We have to see you with the private poor, ask and get answers not just that when we want to really want to understand (verstehen) of reality that is referred to with the word poverty is, we are not merely observing from the outside, although at some stage we have to see from outside to know something. For example, I participated in the all of hope, the feeling, and the struggle is done the poor. In summary, understanding poverty through the process because of poverty ,not seen in an item that stands outside of us, but rather attached to the human self (Hardiman, 2002). 
The results of our sighting from the outside, through it we will, looking for a relationship, looking, for browsing history, and so on. For example, we will find structures that cause why the person is poor, the structure of social, political, or cultural, so getting an empirical analysis of reality. Our understanding of many more in exposing, for example, we will find the complex feelings, desires, or thoughts-think related to poverty. In short, poverty is not just a matter of material objectivity, but rather penetrate the awareness the poorest. We will find structures in of poverty.

Of the two explanations above, to get the reality of poverty requires an inner reality, and also covered up the existence of a physical reality. Our hope is to find the common structures of the most far-reaching and undoubtedly that stands outside the poor with regard to poverty, as well as subjective structures find the ultimate in relating to the awareness of the poor, which is also associated with poverty. With the departure of hope; We will find the arrangement of class society the poor community, a history of the poor, the cultural demands of the poor and so on. From the second we will probably find a perception-think era, perception, attitudes, dispositions-disposition.

\section{The role of sociology in the handling of poverty in Indonesia}

Basically the ethos of social science is the search for truth, objective or looking for realism, a term that means one shows, with an objective view of reality (Gunnar Myrdal, 1981 in Santoso and Santoso, 2003). The extent the social sciences, brought in this case is looking at reality as it is (das sein) using the methodology as well as social theory based on objective reality which made the field investigation. More specifically, is a social science How can free themselves from the legacy: Legacy: the first strong from earlier writers in the field of science is done that sometimes contain normative orientation and the theological and moral fhilosopy based on the metaphysics of natural law as well as utilarianisme which became a source of formation of social theory. Through the efforts of self liberation from any pretense of social interests or to produce objective knowledge in what is, so that the consequences of social studies as the study of human beings with all the symptoms of a social change is acceptable, as is the case with the natural sciences.

Second, influences the whole environment of cultural, social, economic, political and social sciences of the communities where it was grown (Gunnar Myrdal, 1981 in Santoso and Santoso, 2003). Release of social sciences from the influence of the social life instead of enclosing them in the sense that the social science encyclopedia value and interest. This is because, according to Soedjatmoko (1993) many social scientists in the face of social issues is still limited to the scope of the enactment because certain cultures bound, but how the social sciences brings a set of practical importance to the understanding of social issues more objectively.

The issue of poverty, as seen from the perspective of the social sciences is extremely complex, $m$ diverse structures are interrelated and form a so-called reality of poverty. Social sciences as science historieshermeneutics inter subyektif fields highlights the ever fickle, because symptoms occur in a social fact is not dead but rather the opinion of mankind over the symptoms. So that objects in the symptoms of social and even then it took a review of condition in the context of a dynamic interaction. In a review of the context of poverty, the science of social facts explain, poverty not only society but also an explanation of the causes in the process which led to a society in terms of poverty; how the structure that formed, elements of the structure involved, disposition-disposition of structural and cultural, and perception-perception in a dynamic context and objectivity.

Indeed, many among the sociologist or anthropologist who has done sociological studies of poverty in Indonesia, Koentjaraningrat anthropologists call it. In the interest of the Government or the interests of the development of the theory of social selection with regard to the ideological interests in Indonesia at the beginning there is a mentality in Java theory introduced by Koentjaraningrat. This mentality among other theories assume that poverty or obstacles that occur in the process of national development caused by human mental. The social environment of the poor and oppressed sought factor causes at work mentality, so the community needs to be injected mental prerequisites prerequisites-a more encouraging development so that more successful (Koentjaraningrat, 1974).

As one of the sociology of Indonesia who has been working in this perspective of poverty. Since the fifties, as the teaching staff of the Faculty of agriculture, Sayogyo are already interested in the problem of food as the primary basic needs the people of Indonesia. at conclusion the importance of improvement of the family as the main target nutrition, development and idiotic 
measure success of development in Indonesia. Although there has been a province has reached the goal of development, but in Java is still at the level of 1700-1800 calories per head/day. In the mid-1970s growing discussion that extends on the poverty line. Merely holding on to sheer calorie consumption benchmarks and nutrition every head per day is considered less affordable, while looking for other purposes overview of consumption data also still difficult.

Then the next step is to look for patterns of consumption by utilizing data from the SUSENAS BPS. Indeed, this could be questioned how far can reflect the poverty line? However, the consumption patterns of the different walks of life, in rural and urban areas more fully reflect their expenses so it is a proxy that complement the food consumption only (Sajogyo, 1973 in Tjondronegoro, 1996). Therefore, the World Bank is also interested in using SUSENAS data and much to calculate the poverty line Indonesia in their report. True, there are many more among the social scientist has devoted himself to studies of poverty are contextual. As DH. Saving, has been on the trail of poverty caused by attachment to the capital structure of a particular community groups.

\section{Research methods}

The study employs phenomenology and categorized as descriptive qualitative research data sources of the study consist of primary data and secondary data, the instrument of the study was the researcher himself, data were collected by employing in depth interview, observation and documentation, Data were analyzed by conducting data collection, data reduction, data display, and drawing of conclusion.

\section{Results and discussion}

\section{Access and constraints of medical services for the} poor in Indonesia

\section{The constraints of access to health services by the poor in Indonesia}

Poverty and health are two very related to each other. Although the two are unrelated but can now be examined the link between the two. In the course of a society can be distinguished which is classified as a society rich, medium and poor. The existence of such categorization is also promoted in aspects of life, including health aspects of IE. It can be likened to for instance in a family that belongs to the rich quality of life will be much better off including the in the Affairs of his health. This is clearly contrary to the family that belongs to the poor, never paying attention to health in eating they impressed the difficulty. The impact of poverty can be associated with an assortment of things IE one is health and disease. Health and disease are things that cannot be separated from issues of poverty, unless carried out intervention on one or both sides, i.e., at kemiskinannya or his illness. Poverty affects health so poor people become susceptible to various diseases, because they suffered such disorders suffer from poor nutrition, health knowledge, health behavior, bad neighbourhoods, health costs are not available. On the contrary, poverty also affects the health of a healthy community of pressing poverty because a healthy person has an advanced level of education conditions, steady economic stability, investment and savings are adequate so that healthy people can squeeze spending for medical treatment.

The degree of the health of the poor are still low caused because of the difficulty of asking health services. The difficulty of this Ministry is influenced by various factors such as the lack of the ability economically due to the cost of healthcare is indeed expensive. As explained above, there are a few examples of poverty alleviation programs undertaken by the Government which aims to give the community of social protection in the Ministry of basic education and health in particular, with respect to it then asking the poor population to guarantee against health care as mandated in the Law - the Constitution of 1945 , since 2005 it has been attempted to overcome obstacles and constraints through implementation of the policy of health care Assurance Program of the poor that in never achieved through Jamkernas. Although poverty programmes have been implemented, in fact in the field program - the program is experiencing a lot of constraints. This relates to the difficulty of removing the poverty line residents, so many number of society that belongs to the poor. There are still many other problems in the implementation of public health Assurance Program: there are a few poor patients who utilize public health Assurance Program still pulled a number of administration charges.

\section{Follow-up is needed in health care for the poor population}

Increased equity and affordability of health services society implemented inter alia through the holding of free health care for the poor population in health centers and networks, as well as class III hospitals. Through the efforts of this expected level of health status disparity 
between rich and poor residents increasingly reduced. To anticipate the various technical barriers in the field faced by the poor in getting a decent service, such as administrative and procedural barriers, dissemination and advocacy to the institution of the organizers will be further enhanced, in addition to strengthening the monitoring and safeguarding. In addition, it also implemented improved health facilities and infrastructure and networks; construction and repair of hospitals, especially in disaster areas and lagging selectively; drug procurement, procurement of equipment and supplies to health; and the provision of operational and maintenance costs.

Furthermore, the need for improved basic medical services that include at least the increased health promotion, maternal and child health, family planning, nutrition, environmental health, eradication of infectious diseases, and basic treatment; improved health services referral; the development of the Ministry of the family doctor; as well as the enhancement of the role of the community and the private sector in the Organization of health services.

Other efforts in order to increase equalization, health services were implemented through the placement of doctors and paramedical personnel, particularly in clinics and hospitals in the regions lagging behind; improved availability, equitable, quality, and affordability of drug prices and health supplies, especially for the poor; and improvement of the quality of service of community and hospital pharmacy. Through the implementation of various policies and that coupled with progress in the economic and social fields, the extent of expected poor population health will be better.

\section{Factors of social issues}

Social issues in public life are very much going, but actually there are 4 (four) main factors causing the incidence of social problems, such as the following:

\section{Economic factors}

Problems in the economy are usually in the form of unemployment, poverty and problems of others. In this issue typically should be responsible is the Government, because less Government provides field for society. If society is experiencing these problems will lead to community members to take action criminality and economic deprivation can be used as an excuse or justification in doing these actions. Economic factors can also serve as a reference for advanced or whether a country as well as economic factors can affect social issues on aspects prikologis and biological communities.

\section{Cultural factors}

This factor means that the culture that is increasingly growing in the community will have a role that can trigger the onset of social problems. For example, such a marriage at an early age, mating, delinquency in teens and others or like the current state we are being continuously breached the foreign culture. These factors should get attention in a serious because culture in a country may reflect habits of its people. By studying or steeped in religious education may be able to prevent, arouse or filter the incoming foreign culture.

\section{Biological factors}

Next up is the biological factors, these factors can cause the incidence of social problems such as nutrition, infectious disease and others. This happens because of a lack of health facilities and can occur also due to economic conditions or inadequate public education. So most of the biological condition of the community easily contract the disease, to the solution may be at this point with how to improve health facilities and providing knowledge on any member of the public about the prevention as well as giving knowledge about the importance of healthy life patterns as well as the importance of keeping the environment clean.

\section{Psychological factors}

In addition to the factors above, there are also psychological factors, problems such as this can appear if a society psychologically is very weak. Psychological factors also can also appear if a heavy burden of life felt by the communities existing in particular in urban areas, the job stacks up giving rise to stress, then it may cause overflow of emotion that later may trigger conflicts between members of the society

\section{B. The concept of poverty as a social issue}

Indonesia is a country that has a very dense population, especially in large cities. With a population that is very dense, making Indonesia a lot experience social problems. According to the social issues Soekanto Soerjono is a mismatch between the elements of culture or society, endangering the life of social groups. If there is a clash between existing elements can cause disorders 
of social relationships, such as the inherent shakiness in the life of a group or society. The social problems arising out of the occurrence of the striking difference between the values in the community with the existing reality. That can be a source of social problems, namely as a process of social and natural disasters. The existence of social problems in society is defined by the agencies that have a special authority, such as Government, community leaders, social organizations, community consultation, etc.

Social problems can be categorized into four (4) types of factors, namely:

1. Economic factors: Poverty, unemployment, etc.

2. Cultural factors: divorce, juvenile delinquency, etc.

3. Biological factors: infectious diseases, food poisoning, etc.

4. Psychological factors: neuron, the flow of heresy, etc.

Poverty is indeed currently constitutes an obstacle in the community or in the broader scope of Ron. Poverty is becoming a social problem because when poverty start to multiply numbers, then the existing crime will increase. Many people are currently translating poverty as the base causes social and economic problems. Poverty is now becoming a social problem when the stratification of society in respect of already created levels or dividing lines. So the existence of any discrepancy or boundary demarcation in the interaction or communication between people who are at levels below and above it.

Poverty was also very influential towards the environment that will eventually ruin the environment itself. The poor population who pressed for land-will be looking for critical land or land-land conservation as a place of settlement. Land-land that is supposed to serve as a buffer area or the conservation functions will lose the function of the environment after utilized for residential areas. The next, then the result will cause the occurrence of an environmental imbalance.

In addition, poor population would be difficult in terms of looking for jobs, the poor population without livelihoods will make use of the environment, as an effort to meet its needs without considering the ecological norms in force. Because of the insistence of the economy, many residents in meeting the needs of his life entering the actual areas are protected, if not prevented within the period not too long causes the protected area will be reduced even lost at all, which resulted in the loss of function of the environment (as a giver of environmental services). Besides causing crimes that cause problems in terms of social issues.

This has not been able to lift underprivileged and marginalized from the poverty line. It can also be the poverty around us have become part of the mentality of the community so that individuals are finally feeling comfortable with his life,even if visible by naked eye precisely their life in perspective is not feasible, that poverty can also formed with the exploitation of social class on it. The inability of the Government in addressing this problem in difficult to appear in the rules that prohibited poor people such as banning vagrancy, begging, busking and other poor people work in the add rules provide sanctions for those who give donations to those who lead the profession as mentioned above. Where are the spirit and soul of noble act article 34 concerning poor people in this country in the place that reads "poor and abandoned children in State care for someone" In Indonesia the number of poor people's society that is not also the lower course will meet many phenomena like this. A plural society and heterogeneous is not a good support to assist in combating poverty. To discuss the problem of poverty is necessary in identifying what exactly at mean by poor or poverty and how to measure it.

Different concepts will bear the way the different measurements, afterwards in search of dominant factors either cultural or structural nature that causes poverty going on and the last one are looking for a solution to the relevant issues of it. Like what is presented on the role of Sociology Soerjono Soekanto in view the poverty that is sociology investigate common problems in society with the intention of finding and interpreting the facts of the life of society whereas the efforts of the fix is part of social work.

The poor tend to be removed because it is always accused of being a barrier to development and progress. Not all physical and spiritual development is paying attention to the interests of the community. As a result, national development goals to create or reach fair and prosperous society fit the lofty values embodied in the preamble to the CONSTITUTION 45, just embodied in some society or as well as the powers of the central level up in remote corners of the country. And the paradox is, here and there, the marginalized community created and left behind because the victims of development as the poor. Browse poverty is something that is quite complex, there are some notes that could be a reference about poverty especially in Indonesia, namely: 


\section{The existence of poverty due to a high birth rate}

Community groups who do not forward more often and tend to be called the poor laden with poverty. Poverty is also always experiencing growth rapidly increased in number or mainly because the total birth rate.A Birth rate of the poor in third world countries, including in certain areas in Indonesia is high, in certain contexts, disproportionate to the death rate. The growth of extreme poverty is occurring very rapidly in almost all locations or where they are located. Thus, in general, they hardly have anything other than children; because they are not much of a do nothing, other than procreation and reproduction.

\section{They stay poor because closing themselves from outside influences}

Order and regularity of a community in a region are a hereditary heritage. And if the community had contact with another, it will happen later imitate each other each developing artificial results that match the situation and condition. Thus, it is understood that the social relationships between people, and between communities are influencing each other. However, it does not cover the possibility of interaction occurs, though, there is a group or community that is not developed, so that the patterns remain live and static life. As a result, they do not experience the progress means that they remain in his presence that is poverty.

\section{They become poor due to poor family management}

In General, society [towns and villages] there are those who are categorized as rich people. In a sense they have some advantages if compared with others. For the villagers, the excess they called rich people among others have had some ground Persil, over a field of rice paddies and fields, have tens or hundreds of cattle trail, even have more than one wife. Whereas in urban communities, they have more than one home and car, savings and deposits, an established job, and others.

Though it may not be a reference, an assessment of the characteristics of the rich as it is, it has become a common view of the community. However, in line with the changing time, the offspring is generally the third and fourth generation of those who used the rich turns out to be poor. Society or other people who knew him can only tell stories and reminisce about their parents or grandparents they are filthy rich. This occurs because the families of rich client to manage finances or his possessions. May occur, children relied on because of the wealth of the rich don't want to organize themselves with a good education, as a result they become rich people are ridiculous, and because of this there are not able to manage their money well and true. They can only sell the property to satisfy the necessities of life and life. As a result after certain period, their possessions gone, so gradually they become poor.

\section{Conclusion}

Health and poverty have a close relationship, the number of poor people have an impact on public health, the low for that much needed cooperation and synergy mutual help between the masrakat the high income brackets to help poor communities so that will have an impact on the balance in terms of economic, social and more importantly the community will enjoy the help of upperclass society.

\section{Conflict of interest statement}

Author declares that there is no conflict of interest.

\section{References}

Beberapa Teori Sosiologi Tentang Struktur Sosial. Penerbit Rajawali, Jakarta.

Beteile, Andre, 1977. Inequality among men. Oxford: Basil Blackwell \& Mott Charon, 1980.

Daldjoeni, 2004. Pedesaan lingkungan dan Pembangunan. PT Alumni: Bandung ML. Jhingan. 1983. Ekonomi Pembangunan dan Perencanaan. PT Rajagrafindo Persada, Jakarta.

Etzioni-Halevy, E., Etzioni, A. (Eds), 1973. The Meaning of Sociology. Alfred Publishing Co. Inc.

Geertz, C., 1989. Melampaui Positivisme dan Modernitas. Penerbit Kanisius.

Hardati, Puji. dkk., 2007. Pengantar Ilmu Sosial. Fakultas Ilmu Sosial. UNNES Press.

Hardiman, B., 2003. Social Change, Sources, Patterns, and Consequences. Publisher: Basic Books Inc., New York.

Ismid Hadad, Juli, M.P.A., 2003. Makalah Pengentasan Kemiskinan dalam pembangunan berkelanjutan dan perubahan pola produksi yang ramah lingkungan.

Koentjaraningrat, 1993.Involusi Pertanian: Perubahan Ekologi di Kota Indonesia. Terjemahan dari Agricultural Involution. Jakarta: Yayasan Obor.

Marx, K., 1973. Kebudayaan, Mentalitas dan Pembangunan. Jakarta: Penerbit Gramedia.

Santoso, H., Santoso, L., 2003. Historical Materialim Summarized. (Eds.: Etzioni-Halevy, D. E., Etzioni, A.). Social Change, Sources, Patterns, and Consequences. Publisher: Basic Books Inc., New York.

Shanin, T., 1975. Peasant and Peasants Societies. Penguin 
Education. Middlesex, UK

Soedjatmoko, 1993. Dimensi Manusia Dalam Pembangunan. Soekanto, Soerjono., 1983. Filsafat Ilmu Sosial. Gama Media.

Sumardi, Mulyanto. 1985. Kemiskinan dan Kebutuhan Pokok.CV Rajawali, Jakarta

Supriatna, T., 1997. Birokrasi Pemberdayaan dan pengentasan Kemiskinan. Humaniora Utama Press Bandung.

Tjondronegoro, Sediono, M.P., 1996. Dinamika Golongan Lemah Pedesaan. Refleksi Atas Karya Tulis dan pemikiran DR. Sajogyo. Dalam Memahami dan Menanggulangi Kemiskinan di Indonesia (Eds.: Felix M.T., dkk). Grasindo Jakarta.
Websites consulted:

www.akatiga.org.Artikel dan Opini Kemiskinan www.bappenas.go.id.Penanggulangan Kemiskinan www.ekonomirakyat.org edisi April 2003 Tahun II no.2 Prof

Dr Mubyanto.Penannggulangan Kemiskinan di Indonesia www.ekonomirakyat.org.edisi April 2003 Tahun II. Dalle

Danel. Pemberdayaan Masyarakat di Era Otonomi Daerah www.ekonomirakyat.org.edisi Maret 2003 Tahun II.Gregorius Sahdan.Menanggulangi Kemiskina Desa www.wordpress.com.Lingkaran Setan Kemiskinan harus diputus www.wordpress.com.masalah kemiskinan.,Irawan. 1999.

Ekonomika Pembangunan. Yogyakarta : BPFE-Yogyakarta.

\section{How to cite this article:}

Darwis, M. K., 2016. The ministry of public health of marginal social studies perspective in Indonesia. Int. J. Curr. Res. Biosci. Plant Biol. 3(10), 100-109. doi: http://dx.doi.org/10.20546/ijcrbp.2016.310.012 